\title{
Knowledge Attitudes, Practices and Factors Associated with Blood Donation in the Fatick Health District in 2019 (Senegal)
}

\author{
Fatoumata Binetou Diongue1, Oumar Bassoum¹, Jean Augustin Diégane Tine1, Abiboulaye Sall2, \\ Khadim Niang ${ }^{3}$, Mamadou Matar Mbacké Leye ${ }^{1}$, Amadou Ibra Diallo', Adama Faye ${ }^{1}$ \\ ${ }^{1}$ Institute of Health and Development, Cheikh Anta Diop University of Dakar, Dakar, Senegal \\ ${ }^{2}$ Health District of Fatick, Fatick, Senegal \\ ${ }^{3}$ Training and Research Unit in Health Sciences of Sant-Louis, Saint-Louis, Senegal \\ Email: fatima86d@hotmail.fr
}

How to cite this paper: Diongue, F.B., Bassoum, O., Tine, J.A.D., Sall, A., Niang, K., Leye, M.M.M., Diallo, A.I. and Faye, A. (2021) Knowledge Attitudes, Practices and Factors Associated with Blood Donation in the Fatick Health District in 2019 (Senegal). Open Journal of Preventive Medicine, 11, 132-146.

https://doi.org/10.4236/ojpm.2021.114011

Received: February 5, 2021

Accepted: April 5, 2021

Published: April 8, 2021

Copyright $\odot 2021$ by author(s) and Scientific Research Publishing Inc. This work is licensed under the Creative Commons Attribution International License (CC BY 4.0).

http://creativecommons.org/licenses/by/4.0/ (c) (i) Open Access

\begin{abstract}
Introduction: Timely availability of safe blood or blood products is essential for all health care facilities where transfusion occurs, but in many developing and transitional countries, there is still a considerable gap between the need for blood and the supply available. The overall objective was to study knowledge attitudes, practices, and factors influencing blood donation in the general population in Senegal. Methods: This was a cross-sectional descriptive and analytical study conducted among the Fatick health district population from April 1 to 15, 2019. Thus, the sample is based on a two-stage survey. Data collection was conducted through a questionnaire designed, pre-tested, and administered to 466 people by selected and trained enumerators. The data collected on the smartphone was analyzed using Epi Info 7.2.1.0 software. A descriptive and bivariate analysis was performed with a 5\% risk of alpha error. Results: The average age of respondents was 35 years $( \pm 13)$, with 34 years $( \pm 12)$ for women and 38 years $( \pm 15)$ for men, and more than half of them between 20 and 40 years of age. A proportion of $87 \%$ of respondents lived in rural areas and had agriculture as their primary income source. More than half of the individuals (70\%) were married, and $68 \%$ were educated. The level of knowledge of individuals about blood donation was low at $91.8 \%$. On the other hand, more than half of them had good habits (53.65\%). A proportion of $68.0 \%$ of individuals had an intention to donate in the future. However, only $24.68 \%$ of the population surveyed had already donated blood. Eighty percent of the donations were voluntary. However, $26.09 \%$ had repeated this practice. Factors that could influence the practice of blood donation were age, male sex $(\mathrm{ORb}=2.18$ [1.40 - 3. 37]), high level of education, good knowledge
\end{abstract}


of blood donation $(\mathrm{ORb}=2.14[1.07-4.26])$, the existence of a relatives donor $(\mathrm{ORb}=3.4[2.19-5.26])$ and individuals who did not necessarily require permission from a parent or spouse $(\mathrm{ORb}=3.37$ [2.13 - 5.31]). Conclusion: It is necessary to develop mass communication and proximity strategies, also strengthen the blood bank in terms of human resources and logistics to increase voluntary blood donations in the district. An increase and better planning of mobile clinic outings can facilitate and improve voluntary blood donation by improving accessibility to this service.

\section{Keywords}

Knowledge Attitudes and Practices, Associated Factors, Blood Donation, Fatick District, Senegal

\section{Introduction}

Blood transfusion is an indispensable component of health care. It saves millions of lives every year in routine and emergencies, increasingly allows complex medical and surgical interventions, and dramatically improves patients' life expectancy and quality of life with all kinds of acute and chronic conditions. Timely availability of safe blood or blood products is essential for all health care facilities where transfusion is performed. However, there is still a considerable gap between the need for blood and blood availability in many developing and transitional countries [1].

Voluntary non-remunerated blood donation is recognized as essential to the safety and sustainability of the national blood supply. The World Health Organization recommends this type of voluntary and non-remunerated blood donation. Systems based on replacement donation by family or friends of patients in need of transfusion are rarely able to meet clinical demand. In contrast, remunerated donations pose severe threats to both recipients' and donors' health and safety [1].

Developed countries with well-structured health systems and blood transfusion services based on voluntary blood donation can generally meet blood and blood products' demand. On the other hand, in developing and transition countries, chronic blood shortages are common. Large urban centers may have sophisticated health care provision, but a large proportion of the population, particularly in rural areas, often have access to more limited health services where blood transfusion may be at risk or only unavailable [1].

There is a continuous growth in the need for blood products in Senegal, which means that the demand is greater than the supply. This situation is a factor of morbidity and mortality, especially among women in labor. Hemorrhages are responsible for a quarter of maternal deaths in Senegal [2].

This deficiency in blood products is observed to varying degrees in different geographical areas and is dependent on blood donation rates. In high-income 
countries, the voluntary donation rate is $32.1 \%$ compared to $4.6 \%$ for low-income countries [3]. In Senegal, the rate is estimated at $6.2 \%$, with an estimated shortfall of $40 \%$ in 2017 [2].

In Fatick, the rate of blood donation in the overall population is evolving positively since the blood bank's opening in 2015. It thus went from $0.9 \%$ in 2015 to $2.9 \%$ in 2018. The evolution of donations in fixed cabins (volunteers who come to the bank) remains low, with rates ranging from $12 \%$ in 2015 to $16 \%$ in 2018. The mobile cabin trips collected 32 pockets per trip in 2015 and 49 bags in 2018 [4].

The WHO and the International Federation of Red Cross and Red Crescent Societies (IFRC) are committed to efforts to achieve 100\% voluntary blood donation and have a long history of collaboration in the area of blood safety and availability [1].

Studies conducted elsewhere show a correlation between Knowledge, Attitudes, and Practices and voluntary blood donation [1] [5] [6]. Factors that may influence blood donation are age, with an increase in donors over 50 years of age [7] [8] [9] [10], while younger donors are declining in donations. The reasons young people donate blood are more likely to be related to external social pressures or promises of reward [11] [12]. Surveys in most Western countries indicate that more men than women donate blood [13] [14]. Men donate 30\% more often than women [15]. In most non-Western countries, men donate more regularly than women [9] [12] [16] [17] [18].

Few studies have addressed the level of knowledge, attitudes, and practices of individuals and the factors influencing blood donation in the Fatick health district. The results of this study will provide solutions for the timely availability of blood and blood products in health facilities. Thus, the general objective is to study the knowledge, attitudes, practices, and factors associated with blood donation among people aged 18 to 65 in Fatick health district in Senegal.

\section{Methods}

A descriptive and analytical cross-sectional study was conducted among the health district of Fatick population from April 1 to 15, 2019. The study's target population consists of individuals aged 18 to 65 years old living in the health district of Fatick. From this population, all individuals aged 18 to 65 years old residing for at least 6 months in the Fatick health district and present at the survey time are included. In addition to these criteria are the criteria of non-inclusion that are non-consent and the status of health worker.

The sampling is based on two types of units: survey units, in this case, the concessions and statistical units represented by men and women aged 18 to 65 . The study aims to produce results representing the Fatick health district, urban and rural areas, and the district's 09 communes. The sample was drawn stratum by stratum.

Thus, the sample is based on a stratified, two-stage survey. At the first stage, 17 strata (Primary Survey Units-UPS) were drawn from the list of Enumeration 
Areas (EAs) established during the 2013 General Census of Population and Housing, Agriculture and Livestock (GCPHAL), using a systematic draw with probability proportional to size, the size of the UPS being the number of households. An enumeration of households in each of these strata provided a list of households. A sample of 22 households per cluster was drawn at the second stage, in urban and rural areas, with equal probability systematic sampling. A total of 384 households were selected. The concessions' selection is made randomly with the alea function in Excel and the selection of the concession households is carried out from the right.

The sample calculated according to Schwart's formula $\left(n=\left(\varepsilon \alpha^{2} \cdot p \cdot q\right) / i^{2}\right)$ taking into account a $\mathrm{p}$ equal to $50 \%$ (the rate of blood donation in the district is not known), a precision of 5\%, a cluster effect of 1.1 and a percentage of nonrespondents of $10 \%$, is 466 individuals.

Data are collected from a questionnaire developed from the literature review of studies dealing with voluntary blood donation. The questionnaire included socio-demographic characteristics, respondent behaviors, knowledge about blood donation, attitudes towards blood donation, and user satisfaction. The collection was done through individual interviews. The collection was made by interviewers, trained on the content of the questionnaire and the collection methodology. The questionnaire was pre-tested on a small sample.

Data analysis was done on Epi Info 7.2.1.0. A descriptive and analytical study was conducted. In the descriptive part, position and dispersion parameters were calculated for quantitative (mean, standard deviation, median) and qualitative (absolute and relative frequencies) variables. The bivariate analysis made it possible to assess the links between the variables and blood donation practice. The statistical tests of Pearson's Chi2, Fisher's test, and Student's test were required with a $5 \%$ risk of alpha error.

Variables like knowledge level were created from variables that describe knowledge. Thus a rating made it possible to calculate a score and to define the good, average and bad knowledge. The socio-economic level was assessed on the basis of the materials available in the household. A rating of these materials gave a cumulative score. The latter made it possible to create three classes corresponding to the level (high, medium, low) of economic well-being. The materials consisted of air conditioner, television, telephone, refrigerator, radio and also included the characteristics of the dwelling, the source of drinking water supply, energy for lighting and cooking.

Informed consent of study participants was obtained. The data collected is confidential and kept in a safe place.

\section{Results and Tables}

The study involved 466 people aged 18 and 65, with a 100\% response rate.

\subsection{Socio-Demographic Characteristics}

The average age of interviewed people was 35 years ( \pm 13 years) with a median of 
33 years, The mean age for women was $34( \pm 12)$ and $38( \pm 15)$ for men, and The age group, 20 - 40 years, was the most represented with a proportion of $54.08 \%$. The sex ratio was 2.2, predominantly female. Among those interviewed, $32.00 \%$ were uneducated. More than a third (35.00\%) had only a secondary school education, and only $7.00 \%$ had higher education. The Serer ethnic group predominated at $79.40 \%$, and $87.12 \%$ lived in rural areas. Muslims accounted for $90.56 \%$. Married people were in the majority (69.53\%) (Table 1).

\subsection{Economic Characteristics}

The study showed that $39.06 \%$ of those interviewed were unemployed. Farmers accounted for $16.09 \%$. However, $11.16 \%$ of interviewees benefited from the government's Social Safety Nets program dedicated to low-income families. Monthly income was estimated at less than CFA francs 35,000 for nearly two-thirds of the sample (62.00\%) (Table 1). According to the socio-economic level, class distribution was low at $74.03 \%$, while the average and adequate levels represented $17.81 \%$ and $8.15 \%$, respectively.

\subsection{Lifestyle Characteristics}

A proportion of $90.56 \%$ have never smoked, and $95.28 \%$ have never consumed alcohol. The sport was practiced regularly by $21.46 \%$ of the people. In terms of health care demand, $54.29 \%$ had recourse to traditional practitioners. Discussions with third parties about blood donation were often noted at $10.94 \%$. However, $70 \%$ of those interviewed had never had a conversation about blood donation with other people (Table 1).

\subsection{Knowledge about Blood Donation}

More than $50 \%$ of those interviewed knew that blood bags are for free. More than half of both men and women $(63.73 \%$ and $62.45 \%$ respectively) did not known the number of blood donations indicated in the year. The minimum age to donate blood was unknown for $42.92 \%$ of individuals. Otherwise, the maximum age for donating blood was unknown for almost half of the individuals (48.50\%). Chronic non-infectious diseases should not be disqualified from donating blood for about two-thirds of individuals (65.67\%).

On the other hand, the persons interviewed think that alcoholism and smoking should disqualify people from donating blood with $59.23 \%$ and $53.43 \%$ respectively. Concerning blood safety, $85.41 \%$ of the interviewees know that the blood collected is tested before use (Table 2). Among the people interviewed in the study, $71.00 \%$ had already received information about blood donation. The sources of information most often found were television $(52.00 \%)$ and radio (42.00\%). Social networks and newspapers represented $3.93 \%$ and $2.00 \%$, respectively. Known collection sites were the hospital $(66.20 \%)$, the health center (6.30\%), and the health post (19.20\%).

The level of knowledge, assessed based on a score, shows a low level of individuals' knowledge about blood donation at 91.85\% (Table 2). 
Table 1. Distribution of individuals according to socio-demographic, economic, and lifestyle factors $(\mathrm{N}=466)$.

\begin{tabular}{|c|c|c|}
\hline Features & $\begin{array}{l}\text { Absolute } \\
\text { frequency }\end{array}$ & Relative frequency \\
\hline \multicolumn{3}{|c|}{ Socio-demographic factors } \\
\hline \multicolumn{3}{|l|}{ Sex } \\
\hline Female & 321 & 68.88 \\
\hline Male & 145 & 31.12 \\
\hline \multicolumn{3}{|l|}{ Age range } \\
\hline Less than 20 years old & 50 & 10.73 \\
\hline 20 to 40 years old & 252 & 54.08 \\
\hline 40 to 60 years old & 135 & 28.97 \\
\hline More than 60 years old & 29 & 6.22 \\
\hline \multicolumn{3}{|l|}{ Ethnicity } \\
\hline Diola & 5 & 1.07 \\
\hline Pular & 29 & 6.22 \\
\hline Serere & 370 & 79.40 \\
\hline Wolof & 46 & 9.87 \\
\hline Other(s) & 16 & 3.44 \\
\hline \multicolumn{3}{|l|}{ Marital status } \\
\hline Single & 112 & 24.03 \\
\hline Divorced(e) & 13 & 2.79 \\
\hline Married(e) & 324 & 69.53 \\
\hline Widow (widower) & 17 & 3.65 \\
\hline \multicolumn{3}{|l|}{ Place of residence } \\
\hline Rural & 406 & 87.12 \\
\hline Urban & 60 & 12.88 \\
\hline \multicolumn{3}{|l|}{ Religion } \\
\hline Christian & 44 & 9.44 \\
\hline Muslim & 422 & 90.56 \\
\hline \multicolumn{3}{|l|}{ Household size } \\
\hline Less than or equal to 7 persons & 166 & 35.62 \\
\hline More than 7 persons & 300 & 64.38 \\
\hline \multicolumn{3}{|c|}{ Socio-economic factors } \\
\hline \multicolumn{3}{|c|}{ Type of income-generating activity } \\
\hline Agriculture & 75 & 16.09 \\
\hline None & 182 & 39.06 \\
\hline Breeding & 4 & 0.85 \\
\hline Civil servant & 22 & 4.72 \\
\hline Other(s) & 183 & 39.27 \\
\hline \multicolumn{3}{|l|}{ Social Safety Nets } \\
\hline No & 414 & 88.84 \\
\hline Yes & 52 & 11.16 \\
\hline
\end{tabular}




\section{Continued}

\begin{tabular}{|c|c|c|}
\hline \multicolumn{3}{|l|}{ Monthly income } \\
\hline Between 35,000 and 70,000 & 100 & 22.00 \\
\hline Less than $\$ 35,000$ & 290 & 62.00 \\
\hline More than 70,000 & 76 & 16.00 \\
\hline \multicolumn{3}{|c|}{ Lifestyle habits } \\
\hline \multicolumn{3}{|l|}{ Tobacco consumption } \\
\hline Never & 422 & 90.56 \\
\hline Occasionally & 4 & 0.86 \\
\hline Rarely & 10 & 2.14 \\
\hline Often & 13 & 2.79 \\
\hline Very often & 17 & 3.65 \\
\hline \multicolumn{3}{|l|}{ Alcohol consumption } \\
\hline Never & 444 & 95.28 \\
\hline Occasionally & 7 & 1.50 \\
\hline Rarely & 9 & 1.93 \\
\hline Often & 6 & 1.29 \\
\hline \multicolumn{3}{|l|}{ Sport Practice } \\
\hline Never & 268 & 57.51 \\
\hline Occasionally & 32 & 6.87 \\
\hline Rarely & 66 & 14.16 \\
\hline Often & 72 & 15.45 \\
\hline Very often & 28 & 6.01 \\
\hline \multicolumn{3}{|l|}{ Use traditional healers } \\
\hline Never & 213 & 45.71 \\
\hline Occasionally & 56 & 12.02 \\
\hline Rarely & 132 & 28.32 \\
\hline Often & 56 & 12.02 \\
\hline Very often & 9 & 1.93 \\
\hline \multicolumn{3}{|c|}{ Talk about blood donation with other people } \\
\hline Never & 327 & 70.17 \\
\hline Occasionally & 25 & 5.37 \\
\hline Rarely & 59 & 12.66 \\
\hline Often & 51 & 10.94 \\
\hline Very often & 4 & 0.86 \\
\hline
\end{tabular}

\subsection{Attitudes towards Blood Donation}

$28.54 \%$ of interviewees were afraid of the biological control tests. A proportion of $81.55 \%$ thought that the donation should not be intended for family members only. Donating blood was not a source of illness (62.02\%) and was beneficial (64.38\%). Some 48 individuals, 10.30\%, thought that blood donation should be remunerated, and $68.0 \%$ intended to donate in the future (Table 3). Individuals' attitudes were good for $53.65 \%$, average for $36.05 \%$, and bad for $10.30 \%$. 
Table 2. Awareness of blood donation by interviewed individuals $(\mathrm{N}=466)$.

\begin{tabular}{|c|c|c|}
\hline Knowledge about blood donation & $\begin{array}{l}\text { Absolute } \\
\text { frequency }\end{array}$ & $\begin{array}{l}\text { Relative } \\
\text { frequency }\end{array}$ \\
\hline \multicolumn{3}{|l|}{ Free blood bags } \\
\hline No & 74 & 15.88 \\
\hline DK (Doesn't Know) & 144 & 30.90 \\
\hline Yes & 248 & 53.22 \\
\hline \multicolumn{3}{|c|}{ Number of times a man can donate blood in the year } \\
\hline 1 time & 43 & 9.23 \\
\hline 2 times & 91 & 19.53 \\
\hline 3 times & 26 & 5.58 \\
\hline 4 times & 9 & 1.93 \\
\hline DK & 297 & 63.73 \\
\hline \multicolumn{3}{|c|}{ Number of times a woman can donate blood in the year } \\
\hline 1 time & 119 & 25.54 \\
\hline 2 times & 42 & 9.01 \\
\hline 3 times & 12 & 2.58 \\
\hline 4 times & 2 & 0.43 \\
\hline DK & 291 & 62.45 \\
\hline \multicolumn{3}{|l|}{ Minimum interval between two donations } \\
\hline 12 months & 38 & 8.15 \\
\hline 2 months & 9 & 1.93 \\
\hline 3 months & 39 & 8.37 \\
\hline 6 months & 99 & 21.24 \\
\hline DK & 281 & 60.30 \\
\hline \multicolumn{3}{|l|}{ Minimum age to donate blood } \\
\hline 16 years old & 31 & 6.65 \\
\hline 18 years old & 192 & 41.20 \\
\hline 35 years old & 41 & 8.80 \\
\hline 50 years old & 2 & 0.43 \\
\hline DK & 200 & 42.92 \\
\hline \multicolumn{3}{|l|}{ Maximum age to donate blood } \\
\hline 50 years old & 151 & 32.40 \\
\hline 60 years old & 67 & 14.38 \\
\hline 70 years old & 19 & 4.08 \\
\hline DK & 226 & 48.50 \\
\hline No maximum age & 3 & 0.64 \\
\hline \multicolumn{3}{|l|}{ Indications for donating blood } \\
\hline Public Road Accident & 156 & 33.48 \\
\hline Hemorrhagic delivery & 81 & 17.38 \\
\hline Anemia & 157 & 33.69 \\
\hline Other(s) to be specified & 24 & 5.15 \\
\hline DK & 48 & 10.30 \\
\hline
\end{tabular}




\section{Continued}

Can a person with a chronic non-infectious disease donate blood?

No

DK

Yes

Can a person who smokes give blood?

No

DK

Yes

Can a person who drinks alcohol give blood?

No

DK

Yes

Donated blood is tested for safety reasons?

No

DK

Level of knowledge

\subsection{The Practice of Blood Donation}

In the study, $24.68 \%$ of the population interviewed had already donated blood. Of these donors, $80 \%$ have made voluntary non-remunerated donations. Donations for relatives (also non-remunerated) accounted for $8.70 \%$ of cases. Only $26.09 \%$ of individuals made 2 donations, and $60 \%$ had not renewed the act. It was found that $39.48 \%$ of the interviewees have a relative who has had to donate. Previous blood transfusion experiences were also documented among the interviewees $(4.72 \%)$ or close relatives (22.75\%). Among people who have never donated blood, the blocking factors were lack of information in $52.29 \%$, medical contraindication in $5.43 \%$, personal perception of the physical inability in $8.57 \%$, lack of time in $6.57 \%$, difficulty in accessing collection sites in $6.29 \%$, fear of the announcement of test results in $6.57 \%$, fear of unhealthy blood use in $1.14 \%$, fear of injection needle in $0.29 \%$ and other factors in $17.43 \%$. The permission of a parent or spouse is required for $50.43 \%$ of people who want to donate. Among the interviewed, $71.24 \%$ of them prefer a blood collection center. The hospital, currently the only collection site in the region, is selected by $6.22 \%$ of potential donors. We also note that the mobile collection units were among the preferences of the interviewed (18.45\%).

\subsection{Factors Associated with Blood Donation}

The results of this are shown in Table 4 . The mean age was 38 years $( \pm 13)$ for 
Table 3. Surveyed individuals' attitudes toward blood donation $(\mathrm{N}=466)$.

\begin{tabular}{|c|c|c|}
\hline Attitudes towards-to-blood donation & $\begin{array}{l}\text { Absolute } \\
\text { frequency }\end{array}$ & $\begin{array}{l}\text { Relative } \\
\text { frequency }\end{array}$ \\
\hline \multicolumn{3}{|l|}{ Individuals afraid of biological control tests } \\
\hline No & 264 & 56.65 \\
\hline Yes & 133 & 28.54 \\
\hline Without notice & 69 & 14.81 \\
\hline \multicolumn{3}{|l|}{ Think that people should give blood to family members } \\
\hline No & 380 & 81.55 \\
\hline Yes & 69 & 14.81 \\
\hline Without notice & 17 & 3.65 \\
\hline \multicolumn{3}{|c|}{ Think that a person can get a disease from donating blood } \\
\hline No & 289 & 62.02 \\
\hline Yes & 110 & 23.60 \\
\hline Without notice & 67 & 14.38 \\
\hline \multicolumn{3}{|l|}{ Think that there are benefits to donating blood } \\
\hline No & 111 & 23.82 \\
\hline Yes & 300 & 64.38 \\
\hline Without notice & 55 & 11.80 \\
\hline \multicolumn{3}{|l|}{ Think that the blood donation process takes a long time } \\
\hline No & 293 & 62.88 \\
\hline Yes & 61 & 13.09 \\
\hline Without notice & 112 & 24.03 \\
\hline \multicolumn{3}{|l|}{ Think that blood donation should be remunerated } \\
\hline No & 366 & 78.54 \\
\hline Yes & 48 & 10.30 \\
\hline Without notice & 52 & 11.16 \\
\hline \multicolumn{3}{|l|}{ Planning to donate blood in the future } \\
\hline No & 109 & 23.40 \\
\hline Yes & 317 & 68.02 \\
\hline Maybe & 40 & 8.58 \\
\hline
\end{tabular}

donors and 34 years $( \pm 13)$ for those who had not donated blood with $p=0.0019$. Blood donation use was three times higher among those aged 40 years over than those under 20 years of age. The study found no significant relationship between rural and urban blood donors. Individuals with the higher education level donated blood 3.33 times more $(\mathrm{ORb}=3.33$ [1.47 - 7.59]). Men donated blood 2.18 times more than women $(\mathrm{ORb}=2.18$ [1.40 - 3.37]). Individuals with a good level of knowledge about blood donation were 2.14 times more likely to donate blood $(\mathrm{ORb}=2.14[1.07-4.26])$, as were those with good attitudes $(\mathrm{ORb}=5.27[1.83$ 15.18]). Other factors related to blood donation were monthly income, the existence of a relative-donor, and the need for permission from a parent or spouse. 
Table 4. Factors associated with the practice of blood donation.

\begin{tabular}{|c|c|c|c|c|}
\hline \multirow[t]{2}{*}{ Factors } & \multicolumn{2}{|c|}{$\begin{array}{l}\text { Frequency of blood } \\
\text { donation } \mathrm{n}(\%)\end{array}$} & \multirow[t]{2}{*}{$\mathrm{p}$-value } & \multirow[t]{2}{*}{ Raw gold (IC) } \\
\hline & Yes & No & & \\
\hline \multicolumn{5}{|l|}{ Age range } \\
\hline Less than 20 years old & $06(12)$ & 44 & & 1 \\
\hline 20 - 40 years old & $60(23.81)$ & 192 & 0.03 & $2.29[0.93-5.64]$ \\
\hline 40 - 60 years old ( 40 excluded) & $40(29.63)$ & 95 & 0.006 & $3.09[1.22-7.82]$ \\
\hline More than 60 years old & $09(31.03)$ & 20 & 0.0005 & $3.30[1.03-10.53]$ \\
\hline \multicolumn{5}{|l|}{ Sex } \\
\hline Female & $64(19.94)$ & 257 & 0.0003 & 1 \\
\hline Male & $51(35.17)$ & 94 & & $2.18[1.40-3.37]$ \\
\hline \multicolumn{5}{|l|}{ Residence Environment } \\
\hline Rural & $95(23.40)$ & 311 & 0.05 & 1 \\
\hline Urban & $20(33.33)$ & 40 & & $1.63[0.91-2.93]$ \\
\hline \multicolumn{5}{|l|}{ Level of education } \\
\hline Not educated & $24(16.33)$ & 123 & & 1 \\
\hline Primary & $33(26.83)$ & 90 & 0.019 & $1.88[1.04-3.40]$ \\
\hline Secondary & $45(27.61)$ & 118 & 0.009 & $1.95[1.12-3.41]$ \\
\hline Superior & $13(39.39)$ & 20 & 0.003 & $3.33[1.47-7.59]$ \\
\hline \multicolumn{5}{|l|}{ Level of knowledge about } \\
\hline \multicolumn{5}{|l|}{ blood donation } \\
\hline Bad & $100(23.36)$ & 328 & 0.018 & 1 \\
\hline Good & $15(39.47)$ & 23 & & $2.14[1.07-4.26]$ \\
\hline \multicolumn{5}{|l|}{ Attitudes about blood } \\
\hline $\begin{array}{l}\text { donation } \\
\text { Wrong }\end{array}$ & $04(8.33)$ & 44 & & 1 \\
\hline $\begin{array}{l}\text { Wrong } \\
\text { Average }\end{array}$ & $30(17.86)$ & 138 & 0.053 & $2.39[0.8-7.16]$ \\
\hline $\begin{array}{l}\text { Average } \\
\text { Good }\end{array}$ & $81(32.40)$ & 169 & 0.0001 & $5.27[1.83-15.18]$ \\
\hline \multicolumn{5}{|l|}{ Monthly income (FCFA) } \\
\hline Less than $\$ 35,000$ & $60(20.69)$ & 230 & & 1 \\
\hline From 35,000 to 70,000 & $29(29.00)$ & 71 & 0.014 & $2.31[1.08-4.94]$ \\
\hline More than 70,000 & $26(34.21)$ & 50 & 0.008 & $1.99[1.14-3.46]$ \\
\hline \multicolumn{5}{|l|}{ Existence of a relative-donor } \\
\hline No & $44(15.60)$ & 238 & $<0.001$ & 1 \\
\hline Yes & $77(38.59)$ & 113 & & $3.4[2.19-5.26]$ \\
\hline \multicolumn{5}{|l|}{$\begin{array}{l}\text { Need for authorization from a } \\
\text { parent or spouse }\end{array}$} \\
\hline Yes & $33(42.45)$ & 202 & $<0.001$ & 1 \\
\hline No & $82(71.30)$ & 149 & & $3.37[2.13-5.31]$ \\
\hline
\end{tabular}

Individuals who had a close relative donor (38.59\%) were 3.4 times more likely to donate blood than those without a close relative donor (15.6\%), $\mathrm{p} \leq 0.001$. Individuals who did not necessarily require permission from a parent or spouse were 3.37 times more likely to donate blood, $\mathrm{p}<0.001$.

\section{Discussion}

This study's overalls limitations were the lack of multivariate analysis, which would have made it possible to adjust for certain factors and eliminate con- 
founding factors, and the design of cross-sectional study.

The level of knowledge of individuals about blood donation was low at 91.85\%. However, they had good attitudes towards blood donation (53.65\%). About a quarter of the people interviewed (24.68\%) had already donated blood, $80 \%$ of whom had made voluntary non-remunerated donations. Factors associated with blood donation were age, sex, level of education, level of knowledge and attitude towards blood donation, monthly income, the existence of a relative's blood donor, and the need for authorization from a parent or spouse.

In the study, $24.68 \%$ of the population interviewed had already donated blood. These results are close to those of F. Mousavi et al. [10], who found a proportion of $26 \%$ in Iran in 2011. Akbovia et al. [19] found a proportion of 31.7\% in Lomé. Different proportions in different countries (27.6\% in China, $6.1 \%$ in Haiti, $42 \%$ in Moldova, $26.4 \%$ in Tanzania, $31.7 \%$ in Togo, and 38\% in Uganda) were found in the general urban or rural population by E. Lownik et al. [20]. This indicates that less than half of the general populations engage in blood donation. Awareness-raising is needed to urge people to donate blood to remedy this situation. In our study $80 \%$ of cases were voluntary non-remunerated donations and the recipient was anonymous. These results confirm those found at the national level. Senegal has indeed reached the objective of $80 \%$ voluntary donations, set by the WHO-AFRO regional strategy. Significant progress has been made in the regions [21]. Donations were repeated at least once in $26.09 \%$ of cases. It is therefore important to target more first-time donors and to communicate on aspects related to retention.

The mean age was 38 years $( \pm 13)$ among donors and 34 years $( \pm 13)$ among those who had not donated blood with $\mathrm{p}=0.0019$. The study showed that age could influence blood donation. People over 40 years of age were 3 times more likely to donate blood. Duboz P et al. [12] found the same for this age group. F. Mousavi et al. [10] found 1.4 [1.05 - 1.86] (ORb) times and 1.6 [1.21 - 2.24] (ORa) times higher risk in people aged 35 - 65 years.

The proportion of female blood donors was $19.94 \%$, and the proportion of male blood donors was $35.17 \%$. This study shows that men donated blood more than women $(\mathrm{ORb}=2.18[1.40-3.37])$. This trend towards masculinization of blood donation is not recent. H. Javadzadeh Shahshahani et al. [22] found similar results, with women in Yazd donating blood less than men; as did F. Mousavi et al. [10] in a fitted model. Studies in a majority of Western countries also claim that more men than women donate blood Piliavin and Callero [13], Marantidou et al. [14]. Men donate more often than women Cloutier \& CoL [15]. Similarly, in most non-Western countries, men donate more regularly than women [9] [10] [17]. Physiological constitution and unavailability due to pregnancy are factors that hinder blood donation in women. Many women also stop donating when they become pregnant and do not return afterward. Problems with anemia, more intense physical reactions to blood donation, problems with minimum weight limits, cessation of pregnancy, and breastfeeding are the main rea- 
sons cited for the relative absence of women in blood donation practice [23] [24] [25].

According to education levels, populations with higher levels of education were 3.33 [1.47 - 7.59] times more likely to donate, those with secondary education 1.95 [1.12 - 3.41], and those with primary education 1.88 [1.04 - 3.40] times more likely to donate. Thus, the higher level of education increases the practice of donating blood. The results are similar to those of F. Mousavi et al. [10]. Duboz $\mathrm{P}$ et al. [9] showed that higher education graduates were also more likely to be donors.

This study showed that the higher the level of knowledge about donating blood is, the more the person engages in the practice of donating blood $(\mathrm{ORb}=$ 2.14 [1.07 - 4.26]). Overall, the level of knowledge of the interviewees was low in $91.85 \%$ of the individuals. These results are in line with H. Javadzadeh Shahshahani et al. [22], who also found that $54.2 \%$ of the information on blood donation was obtained through radio and television. For our study, this value was estimated at $52.00 \%$ (television) and $42.00 \%$ (radio). K.-K. Agbovi et al. [19] found that men (41.7\%) were more likely than women $(20.7 \%)$ to be aware of the practice of blood donation, with the media (29.8\%), friends (25.5\%), and public awareness (23.4\%) as sources of information. Similarly, good attitudes towards blood donation favor this practice $(\mathrm{OR}=5.27[1.83-15.18])$.

The existence of a relative donor is a factor that can contribute to the practice of blood donation. Indeed, individuals with a close donor are more likely to donate blood $(\mathrm{OR}=3.4[2.19-5.26])$. According to several surveys, family and friends' influence on the first donation significantly impacts [24] [26] [27] [28]. Moreover, studies show that one of the main reasons mentioned by non-donors for not having donated blood before is simply that no one invited them to do so [9] [24] [26].

The study objectified a relationship between the need for authorization or not from a third party (parent or spouse) to donate blood. Individuals who do not necessarily require parental or spousal permission are more likely to donate blood ( $\mathrm{OR}=3.37$ [2.13 - 5.31]). The influence of a parent or spouse is often essential and decisive in health decisions in our regions.

\section{Conclusion}

This work's objective was to study the knowledge, attitudes, practices, and factors that influence voluntary blood donation in the Fatick health district. A problem was noted in the communication of blood donation for the communities. Some factors related to genders, such as age, sex, and education level, influenced the practice of blood donation. There was a statistically significant relationship between voluntary blood donation and the positive or negative influence of relatives. It is necessary to develop mass communication and outreach strategies and strengthen the blood bank in terms of human resources and logistics to increase the district's voluntary blood donations. More and better plan- 
ning and coordination of mobile clinic outings with health development committees and the community network's use to integrate blood donation communication can facilitate and improve voluntary blood donation by improving accessibility to this service.

\section{Conflicts of Interest}

The authors declare no conflicts of interest regarding the publication of this paper.

\section{References}

[1] Organisation Mondiale de la Santé (OMS) (2011) Vers un don de sang volontaire à 100\%: Un cadre d'action mondial. OMS, Genève.

[2] Centre National de Transfusion Sanguine (CNTS) (2017) Plan stratégique de la transfusion sanguine au Sénégal (2017-2021).

[3] Devi, H.S., Laishram, J., Shantibala, K. and Elangbam, V. (2012) Connaissances, attitudes et pratiques en matière de sécurité du don de sang et de don. Gazette Médicale Indienne, 145, 1-5.

[4] Hopital Régonal de Fatick (2018) Rapport annuel banque de sang CHR Fatick.

[5] Launiala, A. (2009) Dans quelle mesure une enquête CAP peut-elle nous renseigner sur les connaissances, les attitudes et les pratiques des personnes? Quelques observations issues de recherches d'anthropologie médicale sur le paludisme pendant la grossesse au Malawi. Anthropology Matters Journal, 11, 1-13.

[6] Chauhan, R., Kumar, R. and Thakur, S. (2018) Une étude pour évaluer les connaissances, les attitudes et pratiques sur le don de sang parmi les étudiants en médecine d'un collège de médecine à Inde du Nord. Journal of Family Medecine and Primary Care, 7, 693-697.

[7] Zou, S., Musavi, F., Notari, E.P., et al. (2008) Changing Age Distribution of the Blood Donor Population in the United States. Transfusion, 48, 251-257.

[8] Bigot, R. (2007) Les Français et le don de sang. Établissement français du sang, Paris.

[9] Duboz, P., Macia, E. and Cunéo, B. (2010) Sociodemographic and Attitudinal Factors to Blood Donation in the Urban Population of Dakar, Senegal. Transfusion, 50, 2713-2720. https://doi.org/10.1111/j.1537-2995.2010.02750.x

[10] Mousavi, F., Tavabi, A.A., Golestan, B., et al. (2011) Knowledge, Attitude, and Practice towards Blood Donation in Iranian Population. Transfusion Medicine, 21, 308-317. https://doi.org/10.1111/j.1365-3148.2011.01080.x

[11] Glynn, S.A., Williams, A.E., Nass, C.C., et al. (2003) Attitudes toward Blood Donation Incentives in the United States: Implications for Donor Recruitment. Transfusion, 43, 7-16. https://doi.org/10.1046/j.1537-2995.2003.00252.x

[12] Kolins, J. and Herron, R. (2003) On Bowling Alone and Donor Recruitment: Lessons to Be Learned. Transfusion, 43, 1634-1638. https://doi.org/10.1046/j.1537-2995.2003.00560.x

[13] Piliavin, J.A. and Callero, P.L. (1991) Giving Blood: The Development of an Altruistic Identity. Johns Hopkins University Press, Baltimore.

[14] Marantidou, O., Loukopoulou, L., Zervou, E., et al. (2007) Factors That Motivate and Hinder Blood Donation in Greece. Transfusion Medicine, 17, 443-450. https://doi.org/10.1111/j.1365-3148.2007.00797.x 
[15] Cloutier, M.S., Apparicio, P., Dubé, J., et al. (2012) Regional Variation in the Modeling of Donation Frequency: The Case of Héma-Québec, Canada. Transfusion, 52, 2329-2338. https://doi.org/10.1111/j.1537-2995.2012.03604.x

[16] Newman, B. (2006) Iron Depletion by Whole-Blood Donation Harms Menstruating Females: The Current Whole-Blood-Collection Paradigm Needs to Be Changed. Transfusion, 46, 1667-1681. https://doi.org/10.1111/j.1537-2995.2006.00969.x

[17] Olaiya, M.A., Alakija, W., Ajala, A., et al. (2004) Knowledge, Attitudes, Beliefs, and Motivations towards Blood Donations among Blood Donors in Lagos, Nigeria. Transfusion Medicine, 14, 13-17. https://doi.org/10.1111/j.0958-7578.2004.00474.x

[18] Javadzadeh Shahshahani, H. (2007) Why Do Women Volunteer to Give Blood? A Study of Knowledge, Attitude and Practice of Women about Blood Donation, Yazd, Iran, 2005. Transfusion Medicine, 17, 451-454.

https://doi.org/10.1111/j.1365-3148.2007.00803.x

[19] Agbovia, K.K., Koloub, M., Fétékéb, L., Haudrechyc, D., Northc, M.L. and Ségbénab, A.Y. (2006) Étude des connaissances, attitudes et pratiques en matière de don de sang. Enquête sociologique dans la population de Lomé (Togo). Transfusion Clinique et Biologique, 13, 260-265. https://doi.org/10.1016/j.tracli.2006.06.002

[20] Lownik, E., Riley, E., Konstenius, T., Riley, W. and McCullough, J. (2012) Knowledge, Attitudes and Practices Surveys of Blood Donation in Developing Countries. Vox Sanguinis, 103, 64-74. https://doi.org/10.1111/j.1423-0410.2012.01600.x

[21] Catin, M., Hazem, M. and Sy, I. (2012) Disparités régionales de pauvreté au Sénégal et déterminants: Un modèle économétrique; communication présentée aux XXVIIIe Journées de l'Association Tiers-Monde, Orléans, juin. Cahiers du LEAD.

[22] Javadzadeh Shahshahani, H., Yavari, M.T., Attar, M. and Ahmadiyeh, M.H. (2006) Knowledge, Attitude and Practice Study about Blood Donation in the Urban Population of Yazd, Iran, 2004. Transfusion Medicine, 16, 403-409. https://doi.org/10.1111/j.1365-3148.2006.00699.x

[23] Alessandrini, M. (2007) Community Volunteerism and Blood Donation: Altruism as a Lifestyle Choice. Transfusion Medicine Reviews, 21, 307-316. https://doi.org/10.1016/j.tmrv.2007.05.006

[24] Misje, A.H. and Bosnes Vet Heier, H.E. (2008) Recruiting and Retaining Young People as Voluntary Blood Donors. Vox Sanguinis, 94, 119-124. https://doi.org/10.1111/j.1423-0410.2007.01004.x

[25] Misje, A.H., Bosnes, V. and Heier, H.E. (2010) Gender Differences in Presentation Rates, Deferrals, and Return Behaviour among Norwegian Blood Donors. Vox Sanguinis, 98, e241-e248. https://doi.org/10.1111/j.1423-0410.2009.01267.x

[26] Misje, A.H., Bosnes, V., Gasdal, O., et al. (2005) Motivation, Recruitment and Retention of Voluntary Non-Remunerated Blood Donors: A Survey-Based Questionnaire Study. Vox Sanguinis, 89, 236-244. https://doi.org/10.1111/j.1423-0410.2005.00706.x

[27] Bednall, T.C. and Bove, L.L. (2011) Donating Blood: A Meta-Analytic Review of Self-Reported Motivators and Deterrents. Transfusion Medicine Reviews, 25, 317-334. https://doi.org/10.1016/j.tmrv.2011.04.005

[28] Glynn, S.A., Kleinman, S.H., Schreiber, G.B., et al. (2002) Motivations to Donate Blood: Demographic Comparisons. Transfusion, 42, 216-225. https://doi.org/10.1046/j.1537-2995.2002.00008.x 